\title{
BELT AND ROAD INITIATIVE OF CHINA
}

\author{
Saba Sahar \\ Dr Ishrat Afshan Abbasi ${ }^{+}$ \\ Dr Ramzan Kolachi ${ }^{\ddagger}$
}

\section{Abstract}

Belt and Road Initiative (BRI) also recognized as One Belt and One Road $(O B O R)$ is currently renowned external policy initiative of China for regional connectivity. It is a massive infrastructure and transportation project. The study attempts to understand this initiative in broader perspective in terms of big changes at regional and global level. This paper argues that BRI is not just a project of building roads and bridges, but it will simultaneously heighten strategic and economic capability of China. Furthermore, it argues that, China's quest to enhance regional connectivity will be purely based on economic activities. In the meantime, Beijing will use its fiscal leverage to influence the policies of aligned countries to line up with its interests. This paper addresses three main questions: What is the significance of BRI with emphasis on its main objectives? How does this initiative help advance China's interests? What are the expected challenges to BRI?

Keywords: Regional connectivity, Trade, Geo-economics, International politics, Gwadar,

\section{Introduction}

Chinese President Xi Jinping promulgated its BRI strategy in the year 2013 in order to strengthen its connectivity with the world. BRI combines projects covering land route and maritime routes. The

\footnotetext{
* PhD Scholar at Department of International Relations, University of Sindh, Jamshoro, Pakistan. Email: saba_solangi@hotmail.com

+ Assistant Professor, Department of International Relations, University of Sindh, Jamshoro, Pakistan. Email:abbasiishrat39@yahoo.com (Corresponding Author)

‡ Teaching Assistant, Department of International Relations, University of Sindh, Jamshoro. Email: ramzanmkolachi@gmail.com
} 
purpose of this project is to enhance trade and transportation among 138 countries of the world throughout Eurasia and beyond (Robbins, 2017). It is the overriding principle of China's foreign and economic policies. BRI is primarily driven by China's economic and political interests. China is employing BRI to assert its hegemony in the region through vast programme of economic integration. This plan creates a network of highways, railway transportation and energy reserves.

Thus, BRI has potential to excavate regional collaboration and progress interconnectivity on trans-continental level. This initiative is crucial to China's rapid economic growth plus peaceful rise. Therefore, the BRI countries can also benefit and it is a tremendous opportunity to them to closely cooperate with China (Ruta, 2018).

\section{Literature Review}

Zhai (2018) believes that anticipated investment of China in this project extents from US \$ 1.4 trillion to US \$ 6 trillion. The work highlights the major challenges that needs to be addressed concerning the successful execution of BRI. Yu (2018) analyses the context or background of BRI. The author has provided detailed and thoughtful analysis of BRI. Li, M (2020) also finds that BRI is aimed to transform China's security policy at global level. Moreover, the Beijing's growing security influence in the Asia-pacific region can lead to the competition between the major powers specially United States and China.

BRI may face several challenges and opportunities in future as it is stated by Karim (2015) that China's proposed project to build deep seaport at Bay of Bengal may result into another great power rivalry. The same is asserted by Vangeli (2017), who discusses China's relationship with sixteen states of Central Asia, South Asia and Europe linked to the BRI as an emblem of paradigm shift in the world both politically and economically. The opportunities of BRI are further identified by Johnston (2018) who believes that under the 
umbrella of BRI major regional trade integration will increase. In addition, BRI is not only well-thought-out initiative to nurture the continuing advancement of China, but it would result into enormous economic development into other developing countries. Meanwhile, the author is of the opinion that along with huge prospective returns of BRI there are massive perils attached to it including the investment in the politically stable developing States.

While discussing the aims of BRI, Cai Peter (2017) highlights that BRI is determined by China's geo-economics and geostrategic goals which are global in nature. The author analyses China's desire to upgrade Chinese industries while exporting Chinese standards for which Chinese leadership wants to achieve its massive economic strategy called "Made in China 2025". It ought to be mentioned here that, made in China strategy is inspired by 4.0 Strategy of Germany and its main objective is to make Chinese manufacturing industry more innovative, and emphasizes quality over quantity that results into restructure the China's small manufacturing industries with low cost.

It is concluded by Frankopan (2018) that BRI is a driving force of $21^{\text {st }}$ century geopolitics. The study identifies three primary motivations behind the BRI; (1) to accommodate China's manufacturing industry with services; (2) to reach out peacefully to energy rich regions and (3) domestic and international security challenges to BRI. The author has investigated that China and U.S are principle rivals and this initiative raises U.S concerns because it views that BRI is opened by China to replace it as a global power.

Rumi Aoyama (2016) asserts that China's new world-wide Strategy to create Belts and Roads has brought a greater modification in the external relations of China. Author views cordial relations between US and China a demand of time but in the meantime he believes that US will not compromise its primary benefits. 


\section{Research Methodology}

This is a qualitative study as all the basic components of quality research have been used in this research such as explanation, discussion and analysis. The data is collected through secondary sources which include newspapers, research Journals, books and articles. The methodology used in this research is based on content analysis.

\section{Historical Overview of Belt and Road Strategy}

The Silk route strategy of China is over 200 years old, established during Han dynasty by Zhang Qian that helped connect China with Central Asia and Middle Eastern region. This route helped Chinese merchants to trade with the people of western region. A century later, another route called oceanic trade route was established. The BRI is called the new silk road of China's vision to regain its past glory (Ramay, 2016) Thus, the modern world is slowly fleeing the rise of East again (Frankopan, 2015).

\section{Objectives and significance of BRI}

The Belt and Road strategy is extremely ambitious project of Chinese overseas investment. However, it has tremendous potential to improve socio economic structure of the world (Tow, 2017). The proposed project can significantly contribute towards politicoeconomic stability of the region. Moreover, the new Silk Road is about increasing connections, improving collaboration among States and finding a way to either work together or manage their competition (Frankopan, 2018).

The geographical scope of BRI has expanded with addition of Uruguay as a first South American country to join the initiative followed by Venezuela to link to the China's Silk Road commercial plan in the year 2018. On the other hand, China has also been actively engaged in promoting its International investment and development 
assistance loans in order to keep safe its international markets and raw-material for its export business. In this context creation of Investment Bank China under has BRIC is significant step. Shanghai Cooperation Organization Bank is also one of the proposals of the same network. This shows commitment of Chinese leadership to shape the regional and international economic dynamics (Landsburg, 2018).

Likewise, the beneficiary countries are likely to find the big opportunity to reduce poverty and bring economic growth using China's considerable economic means. Therefore, China would leverage these needs for its potential political gains because many of these states suffer internal instability and domestic economic struggle. Resultantly, Beijing has invested massive amount of its capital to strengthen their infrastructure and transportation system. There are mainly top five basic objectives of BRI. First, paying considerable attention to refine inter-governments communication about economic growth with emphasis on trade relations through regional collaboration. Second, it plans to create a connection between hard infrastructure such as power grids and transportation system. Third, it ensures smooth trade between the BRI States. Reducing trade barriers and encouraging Free Trade Area (FTA). Fourth, this initiative would encourage development of soft infrastructure with supporting and improving financial integration. Fifth, it aims at bolstering people to people contacts via cultural exchange programs and tourism.

The initiative is aimed to stimulate global economic growth by increasing cooperation in all the above areas. It ought to be mentioned here that, trade integration in South East Asia is fairly advanced and ASEAN region is already promoting free trade zone under the aegis of ASEAN Economic Community. In contrast, South Asia and Central Asia lack regional integration which has been taking place at slower pace (Wolff, 2016). Even so, BRI countries would be in a position to work for the regional integration through trade and investment. In 
order to cover the weakness of forceful infrastructure in BRI region, China plans to work on transport related infrastructure to connect via ports, rail links and roads ( $\mathrm{Lu}, 2018)$.

\section{Belt and Road Initiative: Gains for China}

China is a rising power with its exceptional economic growth and has significantly expanded its global influence over the last several decades. The Belt and Road Initiative reflects Beijing's assertive role in the US led international order. Moreover, the BRI has raised serious debate and concerns among the traditional powers that China is challenging the existing order by establishing its own norms. Meanwhile, China is focusing on its intentions that the initiative is inspired by its domestic aspirations and promoting regional and international cooperation via trade and investments. The BRI is an exemplary initiative that enhances connectivity through Eurasia and beyond (Wei, 2018).

Keeping in view the current scenario China is seeking the high profile efforts in diplomacy but these efforts appear to be the threat to other powers in the world. Similarly, China would be in the position to gain financial leverage over its partner countries and it will allow her to keep them align with her own interests. Besides, BRI entertains significant ability to serve geo-economic as well as geopolitical gains for China within and abroad.

\section{China-Pakistan Economic Corridor (CPEC)}

It is a multi-billion project launched in April 2015 connects Gwadar port to Xinjiang in China. The CPEC project is intended to link China's territorial Silk Road with Maritime Silk Road. In this effort, Gwadar is seen as backbone in CPEC as it provides shortest and safest route to China getting it out from Malacca dilemma. Moreover, it is a gate way to Middle East and Indian Ocean. Thus, China realizes that, enriched connectivity with adjacent countries would assist to mitigate 
cost and transport time which would pave a way for an expansive variety of commodities and services with fewer regulatory hurdles. Therefore, CPEC is vital to China's economic and strategic curiosities in the region. Pakistan believes this corridor will help to revive its economy. Likewise, the construction of rail and road networks along with energy projects, Pakistan would be the biggest beneficiary along with China (Iqbal, 2017). It ought to be mentioned here that, CPEC offers opportunities as well as challenges. The reservations over routes by smaller provinces, security risks for Chinese nationals, internal security threats to Chinese projects especially in Baluchistan and external opposition by India and United States may hinder the projects successful implementation. If properly carried out, the CPEC can bring profound impact on economic development and growth of Pakistan.

CPEC and other such type of corridors will help expand the China's export markets, and also reduce tariffs and transport costs. Moreover, if positively executed the BRI would facilitate to transmit larger portion of world economy towards China. It will help to enhance widespread economic leverage of China. Resultantly, China would be empowered to form the economic standards in the region (China power, 2019).

The geographical significance of Central Asian Republics play vital role in transforming global strategic environment because it is a source of connecting North-South and East West communication. The Central Asian Landlocked States are embedded with huge amount of natural resources but deposits of oil and gas have been defining its major role in the world politics (Chawla, 2018). Moreover, Central Asian Republics (CARs) have been looking to connect with the world and for this purpose China provides them feasible access to other regions. This would reduce their dependence on Russia for trade. 


\section{Challenges to Belt and Road Initiative}

There is no denial that this project has global dynamics and its main focus is upon potential gains. However, there are vast risks and challenges attached to BRI, which cannot be overlooked. These challenges include both traditional and non-traditional security threats. If China is successful to overcome these challenges the realization of BRI would become more likely.

\section{The traditional security threats to BRI}

In order to seek the regional influence great powers have put forward their own regional initiatives. In this regard, U.S has its own strategy of new silk route which was expressed by then Secretary of State Hillary Clinton when she was visiting India in 2011. In her speech at UN general Assembly meeting in September 2011 also mentioned the idea of New Silk Road (Liu, 2017). Likewise, European Union (EU) in 2009 proposed "New Silk Road Plan" to link with energy rich Central Asian countries. The EU has been actively engaged in investing to ensure her own energy security in the Central Asia. However, it has concerns about the regional conflicts and it is reluctant to make mega investment like China. In the year 2012, India, Iran and Russia proposed North South Corridor. It is ought to be mentioned here that, Russia also proposed "Eurasian Union" which aimed to accelerate the regional integration among the Central Asian States (Liu, 2017).

In addition, the territorial disputes are also main hurdles in the successful implementation of the BRI project. Consequently, such issues negatively affect the successful implementation of security assurance. Some of the major issues contain: South China Sea dispute between South East Asian Countries and China. In the year 2014, Sino Vietnam conflict over "Paracel Island's sovereignty" occurred. In addition, there is a clash between China and Japan in the East China Sea over exclusive economic zone and Diaoyu Island. The essence of these issues lies in the interests of regional and extra regional powers. Therefore, China would be unable to seek an acceptable solution to 
these island issues. Resultantly, China would not get all round support from ASEAN countries. This may result into biggest obstacle for China to formulate new round of trade rules. The Kashmir issue between India and Pakistan, Palestine-Israel conflict and border issues between Central Asian States still remain unresolved. For Example, the territorial dispute between Tajikistan and Kyrgyzstan resulted into armed conflict in 2014. Hence, such issues create misunderstandings and lack of trust which negatively affect the overall stability of the region.

Alongside, from U.S perspective Chinese Initiative is designed to replace it as a global power. Therefore, U.S has its own reservations regarding BRI. Consequently, US now is trying to create its own initiatives of massive investment in Asia to counterbalance the BRI initiative. The Indo-US nexus is aimed to retaliate China's cumulative role in the international politics particularly in the Asia-Pacific region. Likewise, India also view China's rise as a threat to its interests in the region. Both India and U.S share convergence of interests as to China's run in the East Asia and Indian Ocean. Therefore, for U.S, India is an allied power against Chinese ruled Asia (Andrew, 2019). It ought to be mentioned here that, Sri Lanka handed over its Hambantota port to China in 2017 in exchange of getting Chinese assistance to repay the foreign loans. While China have faith that Belt and Road is an inclusive edge and China would use policy concessions in the areas like department of sustainability to help assist BRI countries in sustainable development (BBC News, 2019). Therefore, China is fully aware about the skepticism it is facing by its regional and international powers (US, India, Japan).

It is ought to be mentioned here that, maximum number of the BRI countries are struggling to overcome the issues like corruption, terrorism and separatism. Likewise, uncertain situation in some of the countries is vulnerable and political crisis creates deadlock and lake of common consensus over the internal and external policy matters. The political instability in Kyrgyzstan and Tajikistan, instable 
Afghanistan, political situation in Pakistan, instability in Iran and Yemen and Somalia cannot be overlooked by China (Liu, 2017).

\section{Non-traditional Security threats to Belt and Road Initiative}

The upsurge of terrorism as well as extremism is the core concern for China to deal with. There are various terrorist groups having different political and ideological goals but they all oppose secular regimes. It is vital to notice that anti-China reaction in some parts of Central Asia and Africa has caused severe menace to sabotage the project (Saltskog \& Clarke, 2019).

Besides, China not only face external security threats but internal as well. The Uyghur population in the Xinjiang province of China faces political instability and religious extremism. Therefore, China has to deal with not only international but as well as serious domestic security threats. Likewise, maintaining Maritime security is another challenge for the successful operation of this initiative. The large amount of China's oil trade passes through Strait of Malacca. Therefore, China aims to secure the passage of Strait of Malacca. Meanwhile, India and United States have put their reservations that China's Maritime Silk Road (MSR) aims to serve its commercial and military purpose in the Indian Ocean. Also, they allege China for establishing control over world's largest ports and aims to shape the maritime strategic environment (Frank, 2019). Thus, China would use economic power for the pursuit of its geopolitical interests (Singh, 2019).

\section{Conclusion}

The Belt and Road Initiative (BRI) is a mega project, unprecedented in scope and total number of participant countries. At the same time, the initiative is the strategic vision of China that promotes regional connectivity through trade and cooperation. The CPEC is a vital example in this regard. However, there are many potential roadblocks to the successful execution of this project, China is 
determined to cooperate with Pakistan in all dimensions such as economic and security to deal with the internal security challenges and external threats.

Summarizing the goals and objectives of the BRI, one can recognize that, the initiative has become core developmental interest of China. Therefore, Chinese leadership is keen to formulate effective geopolitical and security policies to safeguard BRI investments and projects. The Chinese authorities are very much aware about the risks and securities challenges and have identified the main threats such as territorial and maritime disputes, terrorism, political instabilities, piracy, and security threats to Chinese workers. In this regard, China is seeking cooperation with all BRI countries to strengthen the security capacity of regional states

It is the plan designed to recognize the role of China as a leader of world economy. It is also important to mention that, BRI accommodates the interests of all the parties involved. China is fully determined to make this initiative successful despite of many political and security risks. Therefore, there is a need of cooperation and coordination on the part of all intervening parties to fully realize the execution of this project. Ultimately, BRI holds great significance, but several challenges need to be addressed in order to avoid many loopholes which could be exploited by the sources who want to derail the initiative. 


\section{References}

Andrew, C., and James, M. (2019, May 19). China's massive belt and road initiative, council on foreign affairs. Retrieved from https://www.cfr.org/backgrounder/chinas-massive-belt-and-roadinitiative

BBC (2019, April 25). Belt and Road: China showcases initiative to the world leaders, Business, BBC News. Retrieved from https://www.bbc.com/ news/business-48047877

Cai, P. (2017, March 22). Understanding China's Belt and Road Initiative. Lowy Institute. Retrieved from https://www.lowyinstitute.org/ publications/understanding-belt-and-road-initiative

Chance, A. (2016). American perspectives on Belt and Road Initiative: Sources of concern possibilities for US-China cooperation. Institute for China-America Studies. Retrieved from https://chinausicas.org/wp-content/uploads/2017/02/American-Perspectives-onthe-Belt-and-Road-Initiative.pdf

Chawla, M. I. (2018). Belt and Road Initiative regional and global dimensions. Journal of Political Studies, 25 (1), 81-94.

China Power (2017, December 2). How will the Belt and Road Initiative advance China's interests? Retrieved from https://chinapower.csis.org/china-belt-and-road-initiative/

Frank, F. (2019, October 23). China's maritime One Belt, One Road Initiative under scrutiny for threats to US security. The Epoch Times. Retrieved from https://www.theepochtimes.com/chinas-maritime-one-beltone-road-initiative-under-scrutiny-for-threats-to-ussecurity_3125300.html

Frankopan, P. (2018). The new silk roads: The present and future of the world. Bloomsbury: UK.

Iqbal, K. (2017). Significance and security of CPEC: Pakistani perspective. China Institute of International Studies. Retrieved from http://www.ciis.org.cn/english/2017-11/10/content_40064710.htm

Johnston, A. L. (2018). The Belt and Road Initiative: What is in it for China, 
Asia and the pacific policy studies? Retrieved from DOI: 10.1002/app5.265

Karim, A. M. (2015). China's proposed maritime silk road: Challenges and opportunities with special references to Bay of Bengal region. Journal of International studies, 30 (3), 297-319

Landsburg, H. M. (2018, October 10). A critical look at China's One Belt One Road Initiative. Retrieved from http://www.cadtm.org/A-criticallook-at-China-s-One-Belt-One-Road-initiative

Li, M. (2020). The Belt and Road Initiative: Geo-economics and Indo specific security competition. International Affairs, 96 (1), 169-187

Liu, H. (2017). The security challenges to One Belt One Road initiative and China's choices. Croatian International Relations Review, 23(78), 129147

Lu, H. and Rohr, C. (2018). China Belt and Road Initiative measuring the impact of improving transport connectivity on international trade in the region: A proof of concept study. Retrieved from https://www.rand.org/pubs/research_reports/RR2625.html

OCED (2018). China's Belt and Road Initiative in the global trade, investment and finance landscape. OCED. Retrieved from https://www.oecd.org/finance/Chinas-Belt-and-Road-Initiative-inthe-global-trade-investment-and-finance-landscape.pdf

Ramay, A. S. (2016). China Pakistan Economic Corridor: A Chinese dream being materialized through Pakistan. Islamabad: Sustainable Development Policy Institute.

Richard, G. (2018). China's belt and road imitative, security implications and ways forward for the European Union. Policy Brief, SIPRI.

Robbins, B. (2017). One Belt One Road and history of maritime silk route. EInternational Relations Studies. Retrieved from https://www.eir.info/2017/03/26/one-belt-one-road-and-the-history-of-themaritime-silk-route/

Rumi, A. (2016). One Belt One Road China's new global strategy. Journal of East Asia Studies, 5 (2), 3-22. 
Ruta, M. (2018). Three opportunities and three risks of the belt and road initiative. Retrieved from https://blogs.worldbank.org/trade/threeopportunities-and-three-risks-belt-and-road-initiative

Saltskog, M., and Clarke, P.C. (2018). Little Known security gaps in China's Belt and Road Initiative, The RAND blogs. Retrieved from https://www.rand.org/blog/2019/02/the-little-known-security-gapsin-chinas-belt-and-road.html

Singh, A. K. (2018). Emerging contours of maritime security architecture under the Belt and Road Initiative. Journal of Defense Studies, 12(4), 35-55

Tow, M. D. (2017). One Belt One Road its significance and meaning, China and US Focus. Retrieved from https://www.chinausfocus.com/ finance-economy/one-belt-one-road-initiative-its-meaning-andsignificance

Vangeli, A. (2019). Introduction: New perspectives on China - Central and Eastern Europe relations. Asia Europe Journal, 17(4), 361-368

Wei, L. (2018). China's Belt and Road Initiative: A bellwether of China's role in the global governance. Tsinghua: Centre for global policy Carnegie

Wolff, P. (2016). China's Belt and Road Initiative: Challenges and opportunities. Retrieved from https://www.die-gdi.de/ uploads/media/Belt_and_Road_V1.pdf

Yakov, S., and Larisa, K. (2017). China's economic interests in the One Belt One Road initiative. SHS Web of Conference 39, 01025. Retrieved from DOI: $10.1051 /$ shsconf/20173901025

$\mathrm{Yu}, \mathrm{S}$. (2018). The Belt and road initiative and its associated criminal risks. IALS Student Law Review, 5 (2), 68-75

Zhai, F. (2018). China's belt and Road initiative: A preliminary quantitative assessment. Journal of Asian Economics, 55 (C), 84 -93 